\title{
DIREITO À SAÚdE E (IN)EFICÁCIA SANCIONATÓRIA DA AGÊNCIA NACIONAL DE VIGILÂNCIA SANITÁRIA: ANÁLISE DE CASOS DE 2011 A 2015
}

RIGHT TO HEALTH AND RATIFYING (IN)EFFICIENCY OF THE BRAZILIAN HEALTH REGULATORY AGENCY: ANALYSIS OF CASES OF 2011 TO 2015

Joedson de Souza Delgado ${ }^{1}$ Ivo Teixeira Gico Júnior ${ }^{2}$

Resumo: Neste artigo investiga-se a ação fiscalizadora empreendida pela Agência Nacional de Vigilância Sanitária no exercício de polícia sanitária, no período de 2011 a 2015, apontado para um diagnóstico de (in)eficácia do julgamento das condutas dos particulares que cometem infrações. Trata-se da responsabilização do ilícito a ser apurado no processo administrativo sanitário realizado em diversos atos vinculados à declaração final da decisão colegiada. Baseia-se no levantamento de dados consolidados do Relatório Anual de Gestão de 2014 e 2015, confrontando-os com a legislação sanitária vigente, normativas internas e o atual debate doutrinário sobre a política sancionatória. Objetiva-se questionar a aptidão da Lei de Infrações à Legislação Sanitária (Lei n. 6.437/1977) para desestimular a prática de eventuais ilícitos, bem como da capacidade institucional para atuar na correção das irregularidades, ao mesmo tempo em que traz uma crítica acerca do (des)interesse da Diretoria Colegiada em tornar rápidos e eficazes a instrução, a análise e o julgamento dos feitos.

Palavras-chave: Infração sanitária. Sanção. Penalidades sanitárias. Agência Nacional de Vigilância Sanitária. Relatório de gestão.

\begin{abstract}
This article aims to investigate the auditing activity of Brazilian Health Regulatory Agency as a surveillance policy institution, from 2011 to 2015. This period is the target of a diagnosis of judgment (in)efficiency over surveillance violations. The research comprises the accountability for illicit acts, which have to be investigated during the surveillance administrative process, conducted in several acts bound to the final statement of a joint decision-making. It is also based on consolidated data of the Annual Management Report (20142015), comparing them to the current surveillance legislation, internal norms and the current doctrinaire debate about sanctioning policy. The objective is questioning the Law of Surveillance Violations (Law n. 6.437/1977) capacity to inhibit eventual surveillance illicit acts, as well as it comes up with a criticism regarding Board of Directors lack of interest in making the stages of the process - instruction, analysis and judgment - faster and more effective.
\end{abstract}

Keywords: Sanitary Infraction. Sanction. Surveillance penalties. Brazilian Health Regulatory Agency. Management report.

\footnotetext{
1 Mestre em Direito pelo Centro Universitário de Brasília - UniCEUB; Especialista em Direito Sanitário pela Fundação Oswaldo Cruz; Servidor público na Agência Nacional de Vigilância Sanitária; SEPN 707/907, Via W 5 Norte, Asa Norte, 70790-075, Brasília, Distrito Federal, Brasil; joedson.delgado@hotmail.com

2 Doutor em Direito pela Universidade de São Paulo e em Economia pela Universidade de Brasília; Mestre com honra máxima em Direito pela Columbia University in the City of New York, EUA; Professor do Programa de Pós-Graduação em Direito do UniCEUB; Advogado; gico@ghdadvogados.com.br
} 


\section{Introdução}

A vigilância sanitária se rearticula e se remodela ao longo do tempo. Originária da Europa, a vigilância sanitária no Brasil surgiu da ideia de "polícia médica" nos séculos XVIII e XIX, com o objetivo coletivo de prevenir e controlar as formas de disseminação de moléstias nas cidades ao fiscalizar as embarcações, o comércio de alimentos e os cemitérios; ao regulamentar o exercício de profissões; ao combater o charlatanismo; e ao implantar o saneamento nas áreas urbanas.

Atualmente, esses atos se estruturam nos sistemas de investigação e regulação em vigilância sanitária, os quais acontecem pelo deslocamento de competências sobre questões eminentemente técnicas do Poder Legislativo para o Poder Executivo. Por esse arranjo institucional, busca-se implementar formas mais eficientes de governança da função executiva, por sua vez, não estabelecidas expressamente na Constituição Federal de 1988. ${ }^{3}$

Como em todo sistema regulatório, é necessário conceber regras, posteriormente, monitorar os agentes regulados, e, em caso de desconformidade, cominar-lhes sanções para dissuadir conduta antissanitária. Nesses termos, a regulação contempla-se em vários atos que dependem da natureza do poder que os fundamenta, já que "[...] termos como atos normativos, inspeções e sanções são recorrentes na recente experiência regulatória brasileira." (PALMA, 2014, p. 84).

Na prática da vigilância sanitária, a fiscalização permite verificar o cumprimento da norma jurídica na fabricação de bens valorativos à vida (alimentos, medicamentos, etc.) e na prestação dos serviços públicos com o fito de elidir, reduzir ou evitar riscos reais ou iminentes à saúde humana. Dada a importância dessa política, o Governo Federal decidiu transformar a Secretaria Nacional de Vigilância Sanitária - antiga integrante da administração direta do Ministério da Saúde - em Agência Nacional de Vigilância Sanitária (Anvisa), com atribuições que vão desde o controle sanitário até o estímulo à livre concorrência. ${ }^{4}$

A vocação da Anvisa é imiscuir na dinâmica de mercado preocupações e precauções com a produção, comercialização, importação e propaganda de produtos e serviços que serão ofertados à população de modo a proteger a saúde e maximizar o bem-estar mediante a interferência nos riscos. É válido destacar que a prevenção do risco inclui uma série de atos normativos e educativos, além da atuação coercitiva da polícia sanitária por qualquer meio ou processo.

Particularmente, a Anvisa, como as demais agências reguladoras, exerce o poder de polícia mediante a concepção do poder normativo, do poder preventivo-fiscalizador e do poder punitivo. Entende-se como poder normativo a expedição de regulamentos de execução para realizar suas finalidades regulatórias; já o poder preventivo-fiscalizador permite verificar se as normas estão sendo

\footnotetext{
Para mais esclarecimentos, cf. art. 196, da Constituição Federal (BRASIL, 1988).

4 Para mais esclarecimentos, cf. art. 30, da Lei n. 9.782 (BRASIL, 1999a).
} 
cumpridas; e o poder punitivo como último instrumento a ser aplicado à correspondente sanção regulatória para quem as infringir (FORIGO; BAKI, 2015, p. 322-325).

Saliente, todavia, que o poder de polícia da Anvisa se encontra compartilhado com órgãos ou entidades estaduais, municipais e distrital de vigilância sanitária (Visas), cabendo-lhe coordenar o Sistema Nacional de Vigilância Sanitária (SNVS). Além disso, como em muitos outros setores e atividades reguladas, as infrações e suas respectivas sanções possuem previsões legais genéricas, ficando a regulamentação do que é efetivamente ilícito normatizado pela Diretoria Colegiada (Dicol). ${ }^{5}$

Sobre essa solução pragmática adotada pelo direito administrativo sancionador, verifica-se que funciona um micromecanismo penal com suas formas particulares de normas, ilícitos e instâncias de julgamento. Quadriculam espaços legais vazios (normas penais em branco) que devem ser preenchidos pela Dicol quando a conduta necessita ser complementada por outra norma.

Eis que a norma sanitária desborda entre o limite da lei à norma específica e concreta em prol de objetivos coletivos. Isso porque a Vigilância Sanitária detém o permissivo para elaborar normas dinâmicas a partir da interpretação sistemática do risco sanitário ao definir atos como irregulares envolvendo conteúdo de interesse regional ou mesmo local, no caso das Visas, e, em âmbito nacional, pela Anvisa.

No que se refere à Anvisa, o instrumento operacional para efeito sancionatório se delineia por atos normativos nominados "Resolução da Diretoria Colegiada," e, no caso das Visas, por Decretos, Instruções Normativas e Portarias. Tanto a Anvisa quanto as Visas se apoiam em tipos infracionais de explicitações técnico-científicas relacionados ao risco à saúde, permitindo, assim, condicionar comportamentos, criar obrigações e/ou fixar sanções aos destinatários de tal ação disciplinadora.

Nesse contexto, a instituição pune o ilícito averiguado no Processo Administrativo Sanitário (PAS) que se convalida no risco sanitário. Em razão disso, a operacionalização do risco pelos profissionais de Vigilância Sanitária deve agregar "[...] o conhecimento técnico e o arcabouço legal para controlar um objeto que possui múltiplas dimensões e propriedades, e que requer diferentes formas de investigação" (SILVA; LANA, 2014, p. 18) e a fiscalização sanitária deve ser "[...] exercida, principalmente, por meio de inspeção, análise fiscal ou solicitação formal de esclarecimentos, documentos ou amostras aos responsáveis pelos estabelecimentos e por produtos sujeitos ao controle sanitário." (ARAÚJO; RODERO, 2013, p. 654).

No dia a dia da fiscalização, os servidores autuantes objetivam averiguar a conformidade das atividades privadas com as regras preestabelecidas da vigilância sanitária, podendo gerar ações

\footnotetext{
5 A Anvisa é gerida por uma Diretoria Colegiada composta por até cinco membros, sendo um deles o seu Diretor-Presidente para mandato trienal, permitida uma única recondução. Outros esclarecimentos, cf. art. 53, V, da RDC 61 (AGÊNCIA NACIONAL DE VIGILÂNCIA SANITÁRIA, 2016a).

6 "Art. 53. A Diretoria Colegiada exerce as competências previstas em Lei e no presente Regimento Interno, e manifesta-se pelos seguintes instrumentos decisórios, assim qualificados: [...] V - Resolução de Diretoria Colegiada (RDC): ato que expressa decisão colegiada para edição de normas sobre matérias de competência da Agência, com previsão de sanções em caso de descumprimento." (AGÊNCIA NACIONAL DE VIGILÂNCIA SANITÁRIA, 2016a).
} 
imediatas, corretivas e utilitárias. ${ }^{7}$ Dessas ações decorre a autuação (ato administrativo concreto de natureza sancionatória) a ser apurada no bojo do PAS de forma apolítica, equânime e técnica.

A competência da Anvisa se projeta em várias modalidades a partir de uma metodologia própria de sancionamento. ${ }^{8}$ A mais comum é a multa, que deveria desestimular a prática de novas condutas infracionais, mas agoniza ao comprometer a eficácia da atividade fiscalizatória nos cerca de 2.094 PAS aguardando decisão inicial até junho de 2016, e cerca de 2.645 PAS esperando análise de recurso e/ou juízo de retratação pelas autoridades de primeira instância administrativa., ${ }^{9,10,11}$

Diante desses resultados, nesta pesquisa objetiva-se contribuir com os debates, doutrinários e práticos, sobre a eficácia da política sancionatória formulada pela Anvisa, evidenciada pelo baixo recolhimento das multas e o elevado índice de prescrição da ação punitiva, e, nessa perspectiva, examinar os esforços de diálogo institucional com os agentes regulados, envolvendo prevenção e repressão à prática de infração.

\section{Método}

A metodologia adotada é a pesquisa exploratória e descritiva com o uso da abordagem qualitativa e quantitativa. O levantamento dos dados consubstancia-se nos Relatórios de Gestão - exercício 2014 e 2015 atinentes ao quantitativo de Autos de Infração - com o raio-x das multas aplicadas na competência de 2011 a 2015 erigida em três gráficos: total de multas aplicadas, arrecadadas e canceladas administrativamente; valores correntes efetivamente arrecadados; e PAS versus multas arrecadadas.

Para este fim, utilizaram-se dados públicos sobre o volume de processos prescritos anteriores ao trânsito em julgado, ocorridos entre 2011 e 2014, obtidos em consulta à Anvisa, visto que tal informação não foi publicizada no Relatório de Gestão, exercício 2014 e 2015. O Relatório é apresentado anualmente à sociedade e ao Tribunal de Contas da União (TCU), a quem cumpre a missão

\footnotetext{
7 Servidores autuantes são "[...] os agentes públicos que exercem suas funções por intermédio de leis específicas, nos cargos de especialista em regulação e vigilância sanitária/fiscal, sanitário/fiscal de controle, sanitário/fiscal de saúde pública/técnico de fiscalização sanitária, etc. ou, ainda, por servidores credenciados." (DELGADO, 2013, p. 233).

8 Para mais esclarecimentos, cf. art. 2, I a XIII, da Lei n. 6.437 (BRASIL, 1977).

9 Informação constante do Apêndice A.

10 O julgamento dos recursos administrativos decorrentes de infrações sanitárias na Anvisa, em primeira instância, pertence a algumas Coordenações definidas regimentalmente, podendo ser delegável tal atribuição às autoridades sanitárias competentes do Ministério da Saúde, dos Estados, do Distrito Federal e dos Territórios, enquanto a decisão em segunda instância, indelegável, incumbe à Dicol - segunda e última instância administrativa recursal (BRASIL, 1977, 1999a; AGÊNCIA NACIONAL DE VIGILÂNCIA SANITÁRIA, 2016a).

11 Os autores adotaram a informação repassada pela Ouvidoria da Anvisa em razão do rigor cronológico: "[...] conforme último levantamento realizado em Junho/2016, informamos que a quantidade aproximada de processos aguardando julgamento em $1^{a}$ instância, no âmbito da CAJIS (sede) e nos Estados, com autoridades delegadas, é de 2.094 processos. E, para análise de recurso e juízo de retratação, temos aproximadamente 2.645 processos." Desconsiderou a imprecisa nota da Anvisa relativa ao quantitativo de PAS em circulação ao aduzir pelo e-Sic: "[...] que, na CAJIS/DIMON (Anvisa sede), existem cerca de 600 processos administrativos sanitários aguardando decisão inicial (1ª instância administrativa), e cerca de 1.780 processos administrativos sanitários aguardando análise de recurso para juízo de retratação." Informações constantes do Apêndice A.
} 
institucional de auxiliar o Parlamento à apreciação técnico-administrativa da juridicidade finalística das agências reguladoras. ${ }^{12,13}$

Na fase da coleta de dados, a Anvisa, de plano, denegou a informação sob o pressuposto da "desproporcionalidade". Interposto recurso, a Agência respondeu que, grosso modo, as áreas técnicas - de primeira instância, que instruem e decidem; e as de segunda, que analisam os processos punitivos - não dispõem do quantitativo de PAS prescritos na forma solicitada, todavia a área correcional apurou o total de 1.633 no período de 2011 a $2014 .{ }^{14}$

Para que essa pesquisa fosse concluída foram realizadas análises da literatura especializada - base de dados da ISI, EBSCO, SciELO, PubMed, Scopus, Google Acadêmico (GA) e Conselho Nacional de Pesquisa e Pós-Graduação em Direito (Conpedi); da Biblioteca Virtual em Saúde (BVS), Biblioteca Digital de Teses e Dissertações do Instituto Brasileiro de Informação em Ciência e Tecnologia (IBICT) e da Coordenação de Aperfeiçoamento de Pessoal de Nível Superior (CAPES) -, a partir da busca dos descritores isolados ou em combinações referentes à "infração sanitária" e termos similares. Optou-se por trabalhar com tais indexadores e diretórios pela facilidade de acesso à informação e pela abrangência de conteúdo pesquisado.

Essa etapa resultou em um universo de referências de cunho descritivo, como Pontelo e Castro (2013), Delgado (2013), Lima e Costa (2009) e Pilati (1989). Verificou-se, desde então, a insuficiência das produções acadêmicas ou práticas acerca da eficácia sancionadora da Anvisa e das demais agências reguladoras.

\section{Resultados e discussão}

O PAS é uma investigação administrativa acerca da existência ou não de uma infração sanitária por parte do administrado, que pode ter como desfecho a(o):
a) sanção administrativa;
b) enunciado da ausência da infração ou da responsabilidade da pessoa física ou jurídica a quem se imputou ilícito;
c) arquivamento por inexistência de prova regular;
d) declaração da prescrição da pretensão punitiva estatal.

Uma das dificuldades a ser demonstrada refere-se ao transcurso de tempo hábil entre a autuação e a aplicação da pena pela Anvisa, podendo, então, ocasionar prescrições intercorrente e

\footnotetext{
12 Para mais esclarecimentos, cf. art. 70, da Constituição Federal (BRASIL, 1988).

13 Para mais esclarecimentos, cf. art. 15, da Lei n. 9.782 (BRASIL, 1999a).

14 Informação constante do Apêndice B.
} 
quinquenal nos PAS em curso. ${ }^{15}$ Logo, a ação administrativa deve ser tomada nos prazos legais sob o risco de impossibilitar o julgamento e disseminar o sentimento de que as leis não são cumpridas ou são parcialmente respeitadas. Afinal, de que adianta autuar e não punir? Para quem ou para qual intento político serviria o enfraquecimento das regras sanitárias coercitivas?

Cunha (2016, p. 104) assevera que a sanção pode vir a não ser executada pelas "[...] dificuldades na condução de processos de apuração e na asseguração de um efetivo recolhimento das multas aplicadas [...]" Objetivamente, reconhece quando o Poder Público atrasa seu dever prestacional já falhou por atingir a própria estrutura do Estado de Direito.

Entre as peculiaridades do controle externo na regulação, o TCU acompanha a atuação da Anvisa por meio de Relatório consolidado pela metodologia de preenchimento de quadros com inserção de informações, por regime de competência, das multas por infração sanitária. Significa dizer que o TCU se limita a perquiri-la sobre a ocorrência da prescrição da pretensão executória; por conseguinte, a Anvisa se restringe à divulgação desses dados assentados em quadros sem clareza e objetividade que permitam a sua fácil compreensão pelo cidadão. ${ }^{16}$

A postura técnica do TCU tem relevância restrita para a conformação do poder de polícia sanitária da Anvisa. Ressalta-se, por outro lado, que uma fiscalização rigorosamente ativa por parte do TCU quanto ao exame de critérios técnicos não é desejável nem permitido, sob pena de causar uma espécie de subordinação hierárquica, todavia, para assegurar a adequada prestação do serviço à população, a Anvisa deve ser indagada da ocorrência de prescrição trienal e quinquenal dos PAS por infração.

Nessa perspectiva, registre-se o diagnóstico do TCU sobre a situação atual de

[...] inexistência, na Anvisa, de uma política estruturada e sistematizada para gerir riscos, embora haja práticas isoladas, que evidenciam a intenção da administração da entidade de promover atividades dessa natureza. Um exemplo foi a inclusão, no Planejamento Estratégico da Anvisa para o período 2010 a 2020, de sete diretrizes estratégicas com base na Matriz SWOT (Forças, Oportunidades, Fraquezas e Ameaças). Contudo, para o relator do processo, Ministro José Múcio, houve apenas a identificação dos riscos, sem que houvesse análise das causas, consequências, avaliações de probabilidade e impacto, respostas e comunicação, entre outros aspectos integrantes do gerenciamento de riscos propriamente dito. (BRASIL, 2015, p. 58).

A Auditoria Interna da Anvisa - tendo por função regimental medir e avaliar a eficiência dos outros controles intraorgânicos -, questionada sobre a realização de auditagem nas unidades organizacionais julgadoras de infrações à legislação sanitária federal no que se refere às multas aplicadas entre 2011 a 2015 , respondeu:

\footnotetext{
$\overline{15}$ Para mais esclarecimentos, cf. art. $1^{\circ}$ e art. $1^{\circ}$, $₫ 1^{\circ}$, da Lei n. 9.783 (BRASIL, 1999b).

16 No Ofício 0050/2015-TCU/Secex Saúde, o TCU requer apenas informações sobre a prescrição da pretensão executória em que a Administração Pública perde sua ação punitiva em cinco anos atingindo a execução dos créditos não tributários decorrentes de multa, iniciado com o trânsito em julgado administrativo, conforme art. 1º-A da Lei n. 9.873/1999.
} 
[...] que não houve trabalhos de auditoria no escopo e período solicitado. Adicionalmente, informamos que consta ação de auditoria no Plano Anual de Atividades de Auditoria Interna - exercício 2016 em tema que permeia o escopo solicitado (multas). O trabalho já foi iniciado, possui previsão de finalização para a primeira quinzena de maio $[. . .]^{17,18}$

Nos mesmos moldes, o Ministério da Transparência e Controladoria-Geral da União (CGU), indagado sobre a legalidade finalística da Dicol no tocante às multas sanitárias no período de 2011 a 2015, aduziu que "[...] não realizou auditorias que tratassem sobre a atuação da Agência Nacional de Vigilância Sanitária - Anvisa no julgamento de infrações sanitárias." ${ }^{19}$

O que chama a atenção é o quinquênio de plena ausência de acompanhamento interno da Anvisa e externo do TCU e do CGU, ao permitir que os rumos da gestão do PAS ficassem à deriva, evidenciado pela magnitude de apurações infracionais paralisadas e com demais situações pendentes.

Nos Relatórios Anuais de Gestão, a atividade julgadora da Anvisa limita-se a descrever a penalidade de multa como espécie, sem, contudo, mencionar as outras de cunho sancionatório cabíveis ao cometimento das infrações sanitárias. O volume de 11.454 multas arrecadadas em cinco anos não é de todo ruim, mas é preciso contextualizar com a porção de multas aplicadas no mesmo período (Gráfico 1).

Desse total, observa-se uma média anual de 3.146,4 multas aplicadas, com arrecadação média em 767.8 dos casos, tendo uma média de cancelamento de cinco multas. Contudo, essa média de multas foi elevada principalmente no ano 2011, sendo este bem discrepante dos demais.

No Gráfico 1 é possível visualizar que, em 2011, foram otimizadas ações gerenciais nas atividades de instrução e julgamento em primeira instância dos autos de infração sanitária. A Anvisa, por sua vez, justificou o resultado "[...] como consequência de força tarefa empreendida no processo de trabalho correspondente. Isso influenciou as médias históricas e, por conseguinte, ocasionou o delineamento de previsão de receita superestimada para o exercício de 2013." (AGÊNCIA NACIONAL DE VIGILÂNCIA SANITÁRIA, 2016b, p. 89).

Nessa discussão, as multas aplicadas referem-se ao auto de infração decidido por multa pela autoridade julgadora de primeira instância; multas arrecadadas são multas efetivamente recebidas no exercício por período de competência, livres de descontos ou acréscimos; multas canceladas administrativamente são a decisão inicial de multa que foi arquivada ou convertida em advertência.

\footnotetext{
17 Para mais esclarecimentos, cf. art. 90, II, da RDC n. 61 (AGÊNCIA NACIONAL DE VIGILÂNCIA SANITÁRIA, 2016a).

18 Informação constante do Apêndice C.

19 Informação constante do Apêndice D.
} 
Gráfico 1 - Total de Multas, por status, de 2011 a 2015

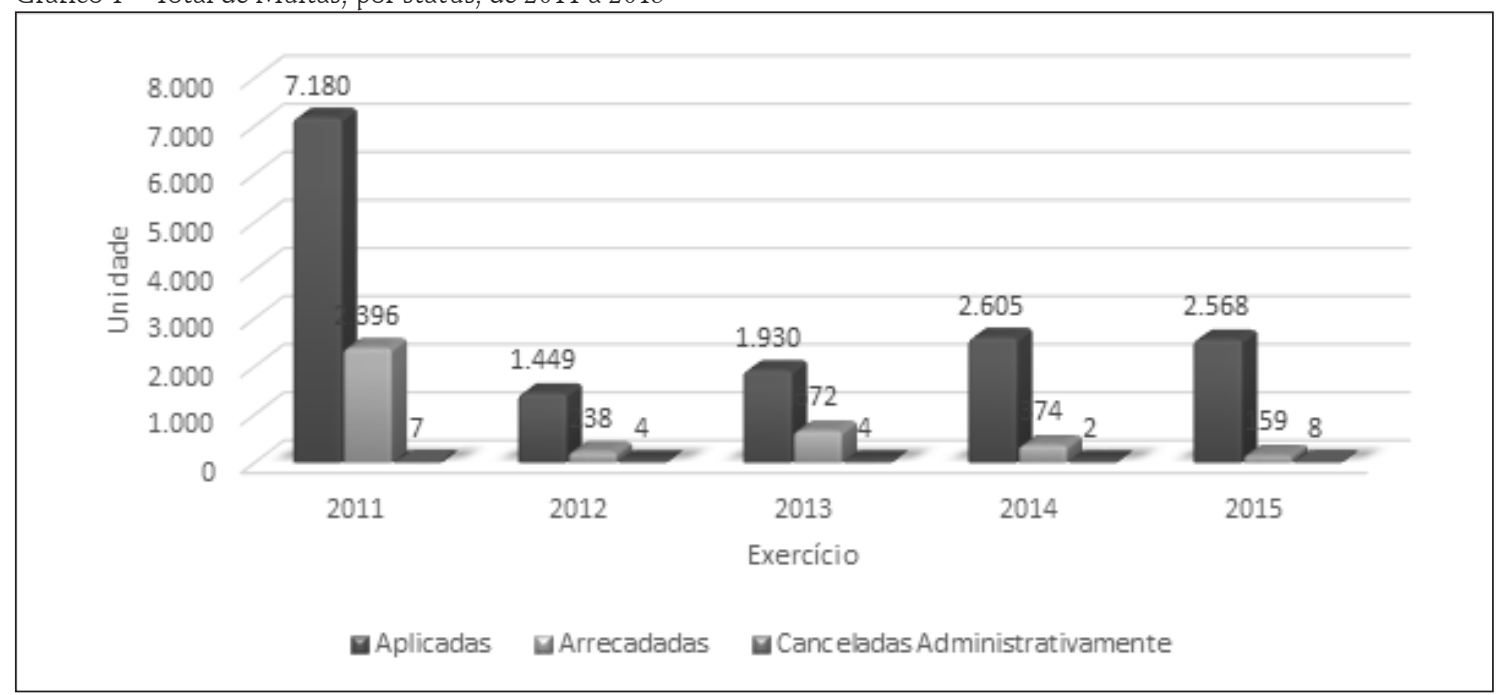

Fonte: elaborado pelos autores a partir da consolidação dos quadros 6.10.1. e 2.5.4.1. de acompanhamento da arrecadação de multa (quantidade), ambos do Relatório de Gestão da Anvisa sobre multas referente aos exercícios de 2014 e 2015 (AGÊNCIA NACIONAL DE VIGILÂNCIA SANITÁRIA, 2015, p. 176, 2016, p. 111).

Observam-se, ainda no Gráfico 1, as oscilações na quantidade de multadas aplicadas, com redução em 79,82\% ${ }^{20}$ de 2011 para 2012. Destaca-se o crescimento no volume em multas aplicadas de 2012 para 2013, aproximadamente 33,20\%, crescendo novamente em 2014, em 34,97\%, e apresentando leve redução de 2014 para 2015, em 1,42\%.

A elevada quantidade de multa, quando se trata da efetividade da arrecadação no ano 2011, 33,37\%, foi a segunda maior, ficando atrás somente do ano 2013, com 34,82\% de arrecadações das multas aplicadas. Para o ano 2012, esta foi a terceira maior efetividade na arrecadação, com $16,43 \%$ de arrecadamento das multas aplicadas, seguida pelo ano 2014, com 14,36\%. A quantidade de cancelamentos das multas foi pequena em 2011, com 0,10\% das multas canceladas, e teve seu ápice em 2014, com 0,31\%, bem superior à média geral de 0,16\%.

Registra-se a oscilação de valores monetários no período de competência da multa arrecadada (2011 a 2015) (Gráfico 2). É claro que não se espera haver uma igualdade entre a quantidade de multas aplicadas e o quantum arrecadado em cada ano, todavia persiste o descompasso em cada exercício reunido no lustro da série.

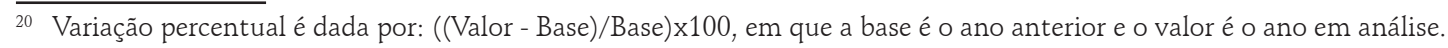


Gráfico 2 - Valores correntes efetivamente arrecadados em reais, 2011 a 2015

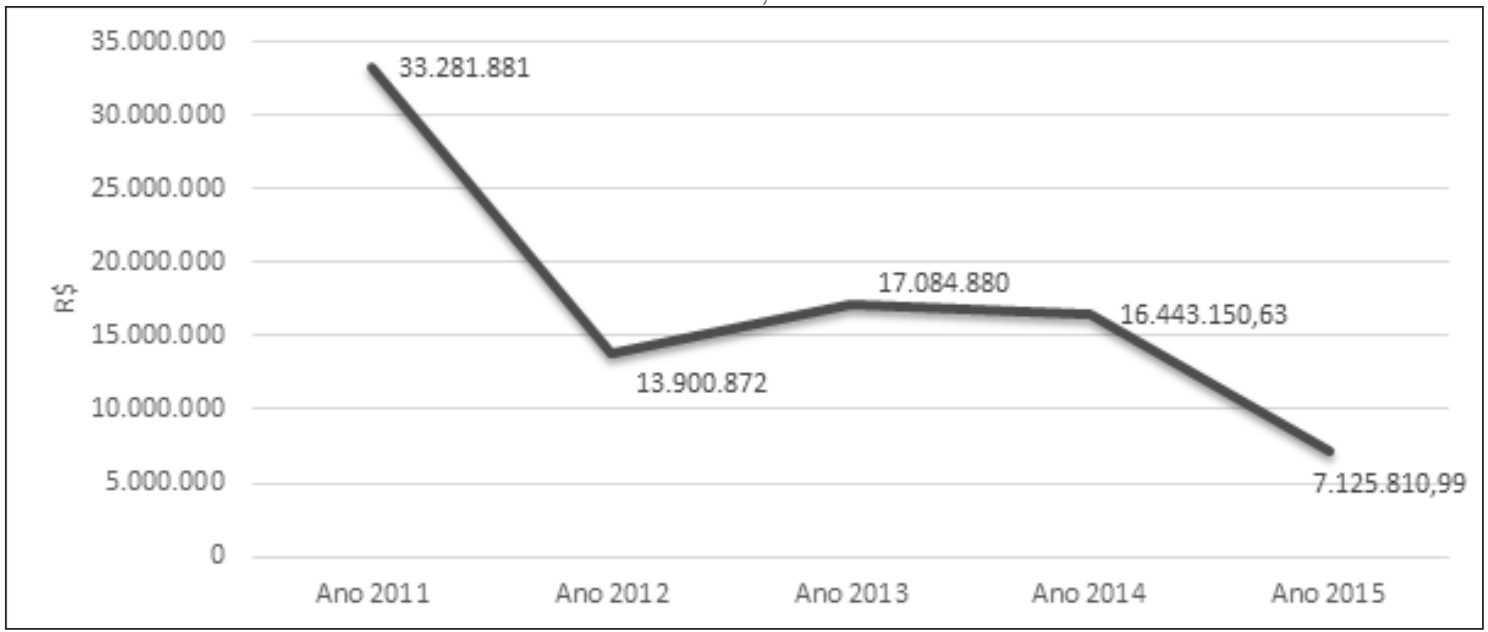

Fonte: elaborado pelos autores a partir da consolidação do Quadro 6.10.3 e 2.5.4.3.de arrecadação efetiva (R $\$ 1,00)$, ambos do Relatório de Gestão da Anvisa sobre multas referente aos exercícios de 2014 e 2015 (AGÊNCIA NACIONAL DE VIGILÂNCIA SANITÁRIA, 2015, p. 178, 2016b, p. 113).

Do cotejamento entre o total de multas (Gráfico 1) com os valores efetivamente arrecadados (Gráfico 2), verifica-se que apenas uma pequena parcela, de 36,10\% em média, das penalidades pecuniárias aplicadas pela Anvisa durante o quinquênio entrou, de fato, nos cofres públicos, remanescendo significativa quantidade de multas não arrecadadas nas mais diversas situações.

De maneira geral, o valor médio das multas durante o período analisado foi de R\$ $15.466,91,{ }^{21}$ tendo o maior valor médio no ano 2014, chegando a R\$ 18.644,19. Já o menor valor médio foi aplicado no ano 2015, aproximadamente R\$ 13.245,00. Observa-se, ainda, que, apesar da maior arrecadação em 2011, esta foi apenas a quarta maior média de valor por multa, R\$13.890,60. Esses resultados mostram maior intolerância da Anvisa em relação aos descumprimentos quanto às normas a serem seguidas, com a elevação nos valores das multas.

Outro dado que chama atenção é a brusca queda em 58,23\% em arrecadações do ano 2011 para 2012, fato este que pode estar relacionado à queda, também, no volume de multas realizadas. Para os períodos seguintes, houve acréscimo em 22,91\% de 2012 para 2013, seguido de redução em $3,76 \%$ para 2014 e, de outra queda brusca em 56,66\% para 2015.

A penalidade sanitária requer a formação da culpa por meio das etapas de análise e julgamento da prática infracional previstas na Lei de Infrações à Legislação Sanitária, na qual inexiste parâmetro escalonador linear, permitindo, assim, que a autoridade estatal puna discricionariamente diante de infrações sanitárias com tipos abertos e penas variadas. Nesse aspecto, Ayres e Braithwaite (1992, p. 19) mencionam uma estratégia regulatória à pacificação de conflitos em que o regulador deve possuir abrangentes formas de sanção a ser aplicada gradativamente, de modo a formar um diálogo efetivo com os infratores.

$\overline{21}$ Quantidade arrecadada dividida pela quantidade de multas arrecadadas. 
Outrossim, a celeridade no processamento das infrações cometidas até a punição é decisiva para reduzir os desvios e aclimatar comportamentos para o cumprimento da lei. Em razão disso, as sanções constantes da Lei de Infrações à Legislação Sanitária tencionam estrategicamente ordenar as ações do setor regulado com interferências no patrimônio e na vida individual/societária.

Experiência bem-sucedida de eficácia sancionatória advém da Agência Nacional de Saúde Suplementar (ANS) a ser replicada na forma de Acordo de Cooperação Técnica com objetivos específicos firmado entre a Anvisa e a ANS. Tal instrumento pode significar o revigoramento do processo sancionatório dada a troca de experiências/informações e a realização de estudos/pesquisas.

Vejamos. Em 2008, a ANS criou a "Notificação de Investigação Preliminar" em que resolvia as reclamações do consumidor com as operadoras de planos de saúde pela mediação, dispensando, assim, a abertura de processo. Em 2011, instituiu o programa "Análise Eficiente de Processos" com o julgamento, em bloco e com idênticas características, de 572 processos em 2011 para 2.032 em 2012. Em 2013, criou uma nova metodologia em que os processos passarão a ser analisados por mutirão com o aporte de 200 servidores temporários admitidos exclusivamente para análise dos processos sancionadores em segunda linha recursal (AGÊNCIA NACIONAL DE SAÚDE SUPLEMENTAR, 2016).

Desde outrora, a Teoria do Ordenamento Jurídico, de Santi Romano, já apontava para as falhas regulatórias. Romano (2008, p. 87-119) afirmou que a sanção não é um elemento essencial do Direito, já que a norma primária necessita de uma segunda norma acessória (sancionatória) que, por sua vez, necessita de uma terceira, e assim continuamente até atingir um ponto em que encerraria qualquer sanção.

Similar entendimento é oferecido por Cruz e Bodnar (2016, p. 244) quanto à forma arcaica de sancionar das estruturas políticas, das instituições e do próprio Direito a serem repensadas e reconfiguradas, sendo "[...] que não pode ser apenas uma técnica simplória de controle social, ou dito de forma clara, de comando e controle, pois deve também estimular e inclusive premiar condutas positivas."

Costa e Rozenfeld (2000, p. 17), por sua vez, entendem que "a redução das práticas da Vigilância ao próprio poder de polícia e à fiscalização, tem produzido sérias distorções”, por isso, além da legislação e da fiscalização, as ações de Vigilância devem empreender outros instrumentos regulatórios, a exemplo do monitoramento da qualidade de produtos e serviços; da atualização/sistematização da base de dados do sistema de informação; da comunicação e educação em saúde; e da vigilância epidemiológica de eventos adversos.

Em linhas gerais, a sanção administrativa não deve ser o fim perseguido, mas uma técnica corretiva ajustada às variáveis individuais que bloqueie a repetição da infração sanitária. No âmbito da Anvisa, o marco regulatório deve ser alterado, dessa vez, concentrado em uma administração para resultados com foco na redução do tempo médio de apuração e de julgamento dos PAS.

Dentro desse contexto, a função educativa avançaria com a exposição do ranking dos maiores infratores pela Anvisa concomitantemente aos potenciais riscos da conduta. A tônica da 
repercussão social remete ao eventual efeito dissuasório perante o setor regulado, já que empresas de grande porte (quase sempre multinacionais), hipoteticamente, teriam maiores preocupações com a imagem, em razão da perda de valor de suas marcas, do que empresas de pequeno e médio porte com menor popularidade em geral.

Outra consideração refere à possibilidade de servir-se de acordos substitutivos à sanção que, com o trânsito em julgado do PAS, podem suspendê-lo até que haja adimplemento de suas obrigações pactuadas ou, ao invés de impor multa por atuação ilícita, a Anvisa estabeleceria acordo decisório com "[...] a obrigação de o agente regulado investir o mesmo montante diretamente na recuperação do dano causado, evitando desperdício de tempo e de recursos públicos." (OLIVEIRA, 2015). Interessante frisar que a consensualidade não impede a decisão sancionatória pela Dicol.

Entre as 10 agências reguladoras, Saddy e Greco (2015, p. 175-179) verificaram que Anac, Aneel, Antaq, Anatel, ANTT e ANP podem realizar acordos de cessação/reparação com o setor regulado, a fim de impedir/substituir procedimentos sancionatórios e da sanção, lastreados em normas regulamentares específicas. Ancine, Ana e Anvisa não têm previsão legal e regulamentar de celebração de Termo de Ajuste de Conduta e da Medida Reparadora de Conduta, no entanto a ANS é o único caso em que esses instrumentos consensuais estão previstos em lei, nos termos dos artigos 29 e 29-A (BRASIL, 1998).

Afora essa solução, o Gráfico 3 expõe os 1.633 PAS prescritos entre 2011 e 2014, representando $34,45 \%$ do total de 4.739 em curso na Anvisa. ${ }^{22}$ Significativa, portanto, a falha na qualidade da burocracia pelos dirigentes que protelaram suas atribuições, visto que nenhum ato processual foi praticado a tempo e a contento de evitá-la.

Em relação aos números absolutos de multas arrecadadas entre 2011 e 2015, o Gráfico 3 mostra um cenário de dificuldade apresentada pela Anvisa com aplicação efetiva da sanção e arrecadação das multas aplicadas.

Observa-se que $34,46 \%$ das multas são prescritas, indicando baixa eficiência na arrecadação. Além disso, a quantidade de multas efetivamente pagas em 2012 reduziu drasticamente em relação ao ano 2011, com redução de mais de $90 \%$. Para o ano 2013, a quantidade de multas arrecadadas cresceu em 182,35\%, com reduções seguidas para o período de 2014 em 44,35\% e nova queda para o período de 2015 em 57,49\%. Tais indícios colocam que xeque a efetividade da arrecadação da Anvisa ou até mesmo a qualidade das avaliações realizadas para a aplicação das multas.

$\overline{22}$ Informações referenciadas em nota de rodapé 12. 


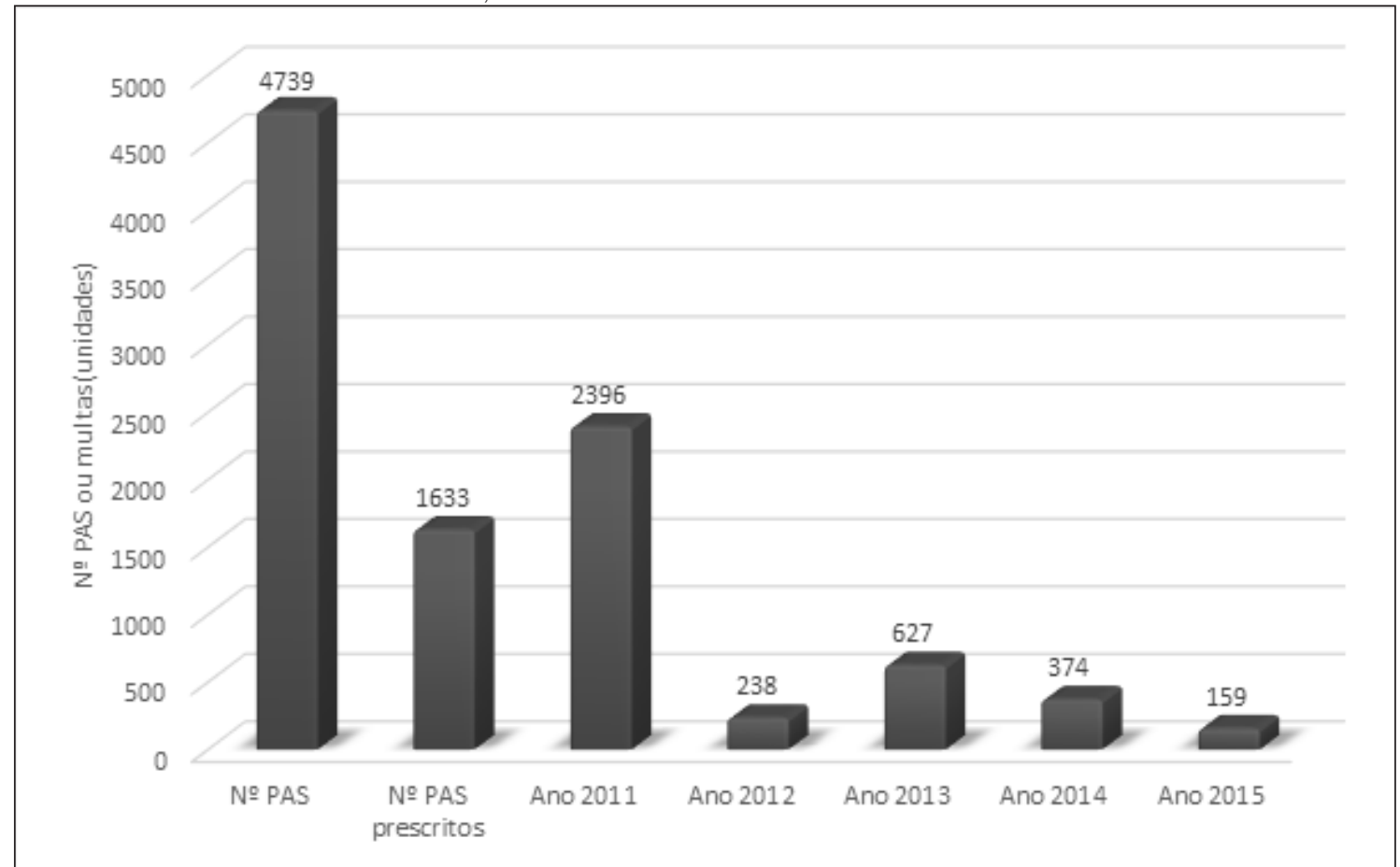

Fonte: elaborado pelos autores a partir da consolidação dos quadros 6.10.1. e 2.5.4.1. de acompanhamento da arrecadação de multa (quantidade), ambos do Relatório de Gestão da Anvisa sobre multas referente aos exercícios de 2014 e 2015 com dados do e-Sic constante do Apêndice B (AGÊNCIA NACIONAL DE VIGILÂNCIA SANITÁRIA, 2015, p. 176, 2016b, p. 111).

Por contemplar uma via processual direta e simplificada, o PAS deveria ter tramitação mais ágil do mesmo modo que o procedimento administrativo dos Juizados Especiais Cíveis e Criminais. ${ }^{23}$ Não menos incomum é a desorganização, a leniência e o descaso institucional com o PAS relativo ao decurso de sua análise e julgamento, além de espaços de frouxidão referente às normas sanitárias, como a inexistência de súmula aprovada pela Dicol, ainda que tenha previsão normativa e inúmeros precedentes. ${ }^{24,25}$

As súmulas no âmbito da Anvisa funcionariam como paradigma para justificação das decisões futuras, mas tal dispositivo é ignorado, e a omissão leva a nocivos interesses políticos e desentendimentos sobre assuntos já pacificados. Assim, a valorização da jurisprudência administrativa aprimoraria a regulamentação do PAS, bem como reduziria o tempo de julgamento da infração, a carga de trabalho e o emprego de dispendiosos recursos.

\footnotetext{
23 Para mais esclarecimentos, cf. art. 2 , da Lei n. 9.099 (BRASIL, 1995).

24 "Art. 53. A Diretoria Colegiada exerce as competências previstas em Lei e no presente Regimento Interno, e manifesta-se pelos seguintes instrumentos decisórios, assim qualificados: [...] VIII - Súmula: ato que expressa a síntese da interpretação da legislação de vigilância sanitária pelo órgão colegiado, a partir de um conjunto de arestos, objeto de reiteradas decisões, revelando vinculação das unidades organizacionais da Agência sobre casos análogos;" (AGÊNCIA NACIONAL DE VIGILÂNCIA SANITÁRIA, 2016a). Para mais esclarecimentos, cf. art. 10, V, $\$ 2^{\circ}$, da Resolução 25 (AGÊNCIA NACIONAL DE VIGILÂNCIA SANITÁRIA, 2008).

25 Informação constante do Apêndice E.
} 
É de grande valia uma gestão institucional mais atenta à proteção da vida e à promoção da saúde, visto que a sociedade como um todo é fiável à atuação profissional da Anvisa. Compreende-se que a demora irrazoável no provimento administrativo afeta o interesse público - entendido como direito fundamental à boa administração -, seja porque o PAS prescreve, seja porque uma decisão proferida em longínqua data à prática infracional pode colocar em risco a eficácia do controle das condutas.

A divulgação da ação reguladora nos Relatórios Anuais de Gestão viabiliza e cinge de uma ampla sindicabilidade dos seus meios e fins. O Congresso Nacional pelo controle político e o controle técnico com o auxílio do TCU; o Poder Executivo Federal (incluindo a própria Anvisa) pelo controle da legalidade administrativa e pelo controle político-administrativo, de caráter hierárquico; o Ministério Público pelo controle jurídico de fiscalização; o Poder Judiciário pelo controle jurisdicional; e o cidadão, individual ou em grupos organizados, pelo controle social. ${ }^{26,27}$

Diante do baixo rigor em apurar a responsabilidade administrativa dos autuados, o TCU elaborou o Termo de Compromisso 019.872/2014-3 com o objetivo de inteirar-se da quantidade de arrecadação das multas aplicadas pela Anvisa e demais órgãos e entidades federais, constatando

[...] a relevância dos achados então apurados - a revelar deficiências sistêmicas nos procedimentos de arrecadação de multas, em prejuízo à própria efetividade das ações de fiscalização e controle exercidos pelas unidades auditadas - deu ensejo a diversas determinações e recomendações com o objetivo nuclear de aprimorar a sistemática de controle e arrecadação de multas administrativas. (BRASIL, 2014, p. 1).

As multas aplicadas que deixam de ser recolhidas e a lentidão da análise processual menosprezam as decisões sancionatórias e, consequentemente, acarretam a fragilização do papel institucional da Anvisa. ${ }^{28}$ De outra parte, Neves (2015, p. 198) assevera que a autuação exprime uma ineficiência peculiar da regulação demonstrando que o "[...] incremento da imposição de multas seria uma espécie de atestado de incompetência da própria agência reguladora em exercer a atividade regulatória."

Para mitigar a situação-problema, a Anvisa detém o instrumento jurídico da Notificação que pode ocorrer previamente à lavratura do Auto de Infração Sanitária (AGÊNCIA NACIONAL DE VIGILÂNCIA SANITÁRIA, 2000, p. 62-67). É a possibilidade de escolha por critérios da oportunidade e conveniência do servidor autuante diante da realidade posta e por fato alheio à vontade

\footnotetext{
${ }_{26}$ A Lei n. 10.180 (BRASIL, 2001) disciplina o controle interno no Executivo Federal dispondo, no art. 22 , inc. I a III, $₫ 1^{\circ}$ a $5^{\circ}$, a Secretaria Federal de Controle como órgão central do Sistema de Controle Interno e o Ministério das Relações Exteriores, Ministério da Defesa, Advocacia-Geral da União e Casa Civil como órgãos setoriais, incluindo o Departamento Nacional de Auditoria do Sistema Único de Saúde (Denasus), como órgão central do Sistema Nacional de Auditoria.

27 Debate jurídico-sanitário de grande repercussão no âmbito da sanção regulatória encontra-se relatado por Delgado e Silva (2015, p. 251-263) em artigo acadêmico publicado na Revista de Direito Internacional (v. 12, n. 1, 2015). O tema, em síntese, refere-se à lacuna deixada pela Súmula 50 da Advocacia-Geral da União (AGU) em que a Anvisa, outrora, responsabilizava o agente marítimo por prática infrativa, sanitária e/ou administrativa, cometidas pelos armadores a bordo da embarcação, nacional ou estrangeira.

28 Para mais esclarecimentos, cf. art. 22, III, da Lei n. 9.782 (BRASIL, 1999b).
} 
do autuado ao fixar novo prazo para o cumprimento da obrigação. Essa oportunidade aumenta a possibilidade de o agente regulado atender aos preceitos sanitários, além de promover o senso de responsabilidade, a qual, se infrutífera, poderá ter seu grau de responsividade aumentado para a estratégia de comando e controle.

Em geral, a maleabilidade do exercício fiscalizatório tem caráter educativo ao permitir que o setor regulado melhore os serviços e propague as exigências técnico-legais, em face a uma cultura draconiana de multas. O que se verifica hoje é o questionamento judicial das multas aplicadas e o seu pagamento, a par do esvaecimento da autoridade sanitária em longo prazo.

A Anvisa convém dar plasticidade às técnicas de controle administrativo, rever os macroprocessos organizacionais, fomentar o debate institucional com o Congresso Nacional para dotá-la de instrumentos adequados ao resguardo/combate das transgressões sanitárias e reformular periodicamente seus sistemas eletrônicos de informações.

Instado o desafio de modernização da gestão: superar e melhor engendrar o atual modelo sanitário sancionador que se limita a regular, monitorar, vigiar, fiscalizar, julgar e punir para a sistemática de regular, monitorar, vigiar, fiscalizar, julgar, educar, orientar, mediar, e só em último caso, punir os infratores.

\section{Conclusão}

Nesta pesquisa revelou-se o descuido da Dicol quanto à gestão dos PAS aliado ao desatualizado arcabouço sancionatório em prevenir/reprimir infrações e persuadir o regulado ao cumprimento espontâneo demonstrado pelo excesso de autuações sem deslinde entre 2011 e 2015. Causa consternação saber que a Anvisa, no seu papel de polícia sanitária, pouco - ou quase nada - refreou o cometimento de novos ilícitos.

A dinâmica sancionatória do PAS, além de ser uma opção onerosa à Administração, não é a melhor em seu propósito de reeducar e recuperar os danos eventualmente causados pelos infratores. Dada a sua relevância em garantir a higidez do setor, a resposta regulatória para o enfrentamento dessa realidade deve ser adequada e proporcional, sem, contudo, ser reducionista, inocente e/ou meramente disciplinar.

A Dicol deve promover uma regulação interativa com representantes de diversos segmentos para melhorar seu processo de fiscalização, a começar por um Grupo de Trabalho; também deve melhorar a forma da divulgação das multas aplicadas, atualmente, limitada a números ou à expressividade de valores.

Há sinais evidentes de que a agenda política das infrações sanitárias reclama uma pauta de debate revisitada e aprofundada sobre o caráter punitivo-pedagógico da autuação, portanto, mais condizente com a racionalidade econômica. É o caso de a Dicol elegê-las como um dos temas 
prioritários da Agenda Regulatória para interlocução com a sociedade, além de adotar providências administrativas voltadas ao congruente gerenciamento do processo.

Saltam aos olhos a alarmante quantidade de PAS prescritos e a não implementação de súmulas administrativas na Anvisa, ambiente que propicia as representações de descrédito e ocaso do seu poder sancionador diante da ideia de impunidade e vantagem compensatória do ilícito. A correção do ato, que deveria repousar no infrator uma certa reflexão pelo mau comportamento, tem funcionado de modo diverso na Anvisa por escapar do seu controle a estratégia/organização do poder de punir.

É nesse contexto que a racionalização das vertentes normativa, preventiva-fiscalizadora e punitiva da Anvisa auxiliarão na boa governança pública para, de agora em diante, consolidar seu papel de independência e credibilidade institucional junto à sociedade. Parece quimérica uma alteração da norma sanitária na esfera legislativa à concepção vanguardista da pena estabelecida na Constituição Cidadã. De qualquer sorte, urge preparar a agenda, politicamente, via Casa Civil da Presidência da República e/ou Comissão de Seguridade Social e Família da Câmara dos Deputados.

Inquestionável que, tanto a lei vigente quanto o modelo organizacional para gerir o PAS não espelham o estágio de responsividade democrática. Neles se punem para apagar o ilícito, não para transformar o infrator. Adjacente à sanção, outros instrumentos com nítida finalidade conciliatória coadunam com uma regulação de melhor custo-benefício, os quais podem estar previstos em lei ou em ato normativo próprio, e, a partir da obediência a alguns requisitos, possibilitam trocar processos sancionatórios pela prevenção e/ou restauração do dano.

Frente a isso, conclui-se que a concretização dos interesses públicos primários, dentro do possível, envolve um convite à participação social no planejamento, na execução, no controle e na discussão sobre sanções administrativas no âmbito da Anvisa. Daí emerge a legitimidade, e a credibilidade da vontade estatal, de outro modo, ressoa em consequências deletérias à coletividade.

Sugere-se que pesquisas futuras analisem a relação entre causa e efeito da redução do quantitativo de multas aplicadas e arrecadadas, já que tal proposta sairia desse escopo. Outra possibilidade a ser estudada seria uma análise aprofundada do baixo volume de multas arrecadadas em relação ao total aplicado.

\section{Referências}

AGÊNCIA NACIONAL DE SAÚDE SUPLEMENTAR. Esclarecimento sobre processos na ANS. Disponível em: <https://is.gd/F0shvp>. Acesso em: 19 ago. 2016.

AGÊNCIA NACIONAL DE VIGILÂNCIA SANITÁRIA. Relatório de Gestão do exercício de 2014. Brasília, DF, 2015. Disponível em: <https://is.gd/pBL9py>. Acesso em: 17 jun. 2016.

AGÊNCIA NACIONAL DE VIGILÂNCIA SANITÁRIA. Relatório de Gestão do exercício de 2015. Brasília, DF, 2016b. Disponível em: <https://is.gd/9x3KCY>. Acesso em: 28 ago. 2016. 
AGÊNCIA NACIONAL DE VIGILÂNCIA SANITÁRIA. Resolução - RDC nº 61, de 03 de fevereiro de 2016. Aprova e promulga o Regimento Interno da Agência Nacional de Vigilância Sanitária ANVISA e dá outras providências. Diário Oficial da União, Brasília, DF, n. 25, Seção 1, p. 67-92, 05 fev. 2016a.

AGÊNCIA NACIONAL DE VIGILÂNCIA SANITÁRIA. Resolução - RE n² 2, de 28 de novembro de 2000. Dispõe sobre a padronização de modelos para os atos de competência legal no exercício de atividades de fiscalização no âmbito da agência nacional de vigilância sanitária. Diário Oficial da União, Brasília, DF, n. 229-E, Seção 1, p. 62-77, 29 nov. 2000.

AGÊNCIA NACIONAL DE VIGILÂNCIA SANITÁRIA. Resolução - RE nº 25, de 4 de abril de 2008. Dispõe sobre o procedimento de recurso administrativo no âmbito da Agência Nacional de Vigilância Sanitária e dá outras providências. Diário Oficial da União, Brasília, DF, n. 66, Seção 1, p. 36-37, 07 abr. 2008.

AYRES, Ian; BRAITHWAITE, John. Responsive regulation: transcending the deregulation debate. New York: Oxford University Press, 1992.

ARAÚJO, Cristiana Martins do Couto; RODERO, Simone. Ações de Fiscalização Sanitária. In: VIEIRA, Fernanda Pires; REDIGUIERI, Camila Fracalossi; REDIGUIERI, Carolina Fracalossi. (Org.). A regulação de medicamentos no Brasil. Porto Alegre: Artmed, 2013.

BRASIL. Constituição. República Federativa do Brasil de 1988. Brasília, DF: Senado Federal, 05 out. 1988.

BRASIL. Decreto n. 7.724, de 16 de maio de 2012. Regulamenta a Lei n ${ }^{\circ} 12.527$, de 18 de novembro de 2011, que dispõe sobre o acesso a informações previsto no inciso XXXIII do caput do art. $5^{\circ}$, no inciso II do $₫ 3^{\circ}$ do art. 37 e no $\$ 2^{\circ}$ do art. 216 da Constituição. Diário Oficial da União, Brasília, 18 nov. 2011.

BRASIL. Lei n. 10.180, de 06 de fevereiro de 2001. Organiza e disciplina os Sistemas de Planejamento e de Orçamento Federal, de Administração Financeira Federal, de Contabilidade Federal e de Controle Interno do Poder Executivo Federal, e dá outras providências. Diário Oficial da União, DF, Brasília, 07 fev. 2001.

BRASIL. Lei n. 9.099, de 26 de setembro de 1995. Dispõe sobre os Juizados Especiais Cíveis e Criminais e dá outras providências. Diário Oficial da União, Brasília, DF, 26 set. 1995.

BRASIL. Lei n. 9.656, de 3 de junho de 1998. Dispõe sobre os planos e seguros privados de assistência à saúde. Diário Oficial da União, Brasília, DF, 03 jun. 1998.

BRASIL. Lei n. 9.782, de 26 de janeiro de 1999. Define o Sistema Nacional de Vigilância Sanitária, cria a Agência Nacional de Vigilância Sanitária, e dá outras providências. Diário Oficial da União, Brasília, DF, 27 jan. 1999a.

BRASIL. Lei n. 9.783, de 23 de novembro de 1999. Estabelece prazo de prescrição para o exercício de ação punitiva pela Administração Pública Federal, direta e indireta, e dá outras providências. Diário Oficial da União, Brasília, DF, 24 nov. 1999 b. 
BRASIL. Lei n. 6.437, de 20 de agosto de 1977. Configura infrações à legislação sanitária federal, estabelece as sanções respectivas, e dá outras providências. Diário Oficial da União, Brasília, DF, 20 ago. 1977.

BRASIL. Tribunal de Contas da União. Monitoramento. Grupo I - Classe VII - Plenário TC 019.872/2014-3. Brasília: TCU, 2014. Disponível em: <https://is.gd/riY3aa>. Acesso em: 09 jun. 2016.

BRASIL. Tribunal de Contas da União. Relatório Trimestral de Atividades: $2^{\circ}$ trimestre de 2015. Brasília, DF: TCU, 2015. Disponível em: <https://is.gd/KrVaZN>. Acesso em: 17 jun. 2016.

COSTA, Ediná Alves; ROZENFELD, Suely. Constituição da Vigilância Sanitária no Brasil. In: ROZENFELD, Suely (Coord.). Fundamentos da Vigilância Sanitária. Rio de Janeiro: Editora Fiocruz, 2000 .

CUNHA, Marcelo Barros da Responsividade do Sistema Sancionatório da Radiodifusão Brasileira. Revista de Direito Setorial e Regulatório, Brasília, v. 2, n. 1, p. 87-106, mai. 2016. Disponível em: < https://is.gd/yeTt9P>. Acesso em: 22 jun. 2016.

CRUZ, Paulo Márcio; BODNAR, Zenildo. Cosmopolitismo e governança transnacional ambiental: uma agenda para o desenvolvimento sustentável. Revista Direitos Humanos e Democracia, a. 4, n. 7 , jan./jun. 2016. Disponível em: <https://is.gd/pUVFDL>. Acesso em: 12 ago. 2016.

DELGADO, Joedson de Souza; SILVA, Ana Paula Henriques da. A fiscalização sanitária das embarcações em águas jurisdicionais brasileiras - notas acerca da (in)efetividade da Súmula 50 da AGU. Revista de Direito Internacional, Brasília, v. 12, n. 1, p. 251-263, 2015. Disponível em: <http://dx.doi. org/10.5102/rdi.v12i1.3358>. Acesso em: 24 out. 2016.

DELGADO, Joedson de Souza. O processo administrativo-sanitário como instrumento de efetividade das ações de vigilância sanitária. Tempus: Actas de Saúde Coletiva, Brasília, DF, v. 7, n. 1, p. 225-240, 2013. Disponível em: <http://dx.doi.org/10.18569/tempus.v7i1.1290>. Acesso em: 22 jul. 2016.

FORIGO, Camila Rodrigues; BAKI, Amália Pasetto. O princípio da legalidade e as agências reguladoras: uma análise a partir da resolução-Antaq n 3274/2014. In: GABARDO, Emerson; PONTES FILHO, Valmir (Coord.). Problemas emergentes da administração pública. CONGRESSO BRASILEIRO DE DIREITO ADMINISTRATIVO, 28., 2015, Belo Horizonte. Anais... Belo Horizonte: Fórum, 2015.

LIMA, Yara Ramos Lima; COSTA, Edina Alves. O processo administrativo no âmbito da vigilância sanitária. In: COSTA, Ediná Alves (Org.). Vigilância Sanitária: temas para debate. Salvador: EDUFBA, 2009. Disponível em: <https://is.gd/70VWfY>. Acesso em: 28 jan. 2016.

NEVES, Sérgio Luiz Barbosa. Limites à função sancionatória das agências reguladoras de serviços públicos. In: DIAS, Maria Tereza Fonseca; SILVA, Lucas Gonçalves da; CALDAS, Roberto Correia da Silva Gomes (Coord.). Direito administrativo e gestão pública I. CONPEDI/UFMG/FUMEC/Dom Helder Câmara (Org.). Florianópolis: CONPEDI, 2015. Disponível em: <https://is.gd/4WGQ1o> . Acesso em: 23 jun. 2016.

OLIVEIRA, Rafael Carvalho Rezende. Novo perfil da regulação estatal: Administração Pública de resultados e análise de impacto regulatório. Rio de Janeiro: Forense, 2015. 
PALMA, Juliana Bonacorsi de. Regulação e autoridade: o poder sancionador na regulação. In: MEDAUAR, Odete; SCHIRATO, Vitor Rhein (Coord.). Poder de polícia na atualidade: Anuário do Centro de Estudos de Direito Administrativo, Ambiental e Urbanístico do ano de 2011. Belo Horizonte: Fórum, 2014. p. 79-107.

PILATI, José Isaac. O processo administrativo sanitário na federação brasileira. Dissertação (Mestrado em Direito)-Centro de Ciências Jurídicas, Universidade Federal de Santa Catarina, 1989. Disponível em: <https://is.gd/5kGFAl>. Acesso em: 17 jun. 2016.

PONTELO, Betânia Maira; CASTRO, Larissa de Paula Gonzaga e. Análise comparativa entre normas do processo administrativo sanitário. $8^{a}$ Mostra de Produção Científica da Pós-Graduação Lato Sensu da PUC Goiás, nov. 2013. Disponível em: <https://is.gd/eo5PVT>. Acesso em: 22 nov. 2016.

ROMANO, Santi. O ordenamento jurídico. Tradução Arno Dal Ri Júnior. Florianópolis: Fundação Boiteux, 2008.

SADDY, André; GRECO, Rodrigo Azevedo. Termo de ajustamento de conduta em procedimentos sancionatórios regulatórios. Revista de Informação Legislativa, v. 52, n. 206, abr./jun. 2015. Disponível em: <https://is.gd/RNw86o>. Acesso em: 19 jun. 2016.

SILVA, Ana Valesca Fernandes Gilson; LANA, Francisco Carlos Felix. Significando o risco sanitário: modos de atuação sobre o risco na vigilância sanitária. Vigilância sanitária em debate: sociedade, ciência e tecnologia, v. 2, n. 2, p. 18, 2014. Disponível em: < http://dx.doi.org/10.9732/P.0034-7191. 2016V112P89>. Acesso em: 20 jun. 2016. 


\begin{abstract}
APÊNDICE A
Pedido de informações dos autores registrada na Ouvidoria da Anvisa sob o n 675076 pelo site http://portal.anvisa.gov.br/fale-com-a-ouvidoria

[...] Solicito informações sobre:

(i) o quantitativo geral de processos decorrentes de infração à legislação sanitária que se encontram: - aguardando decisão inicial ( $1^{\mathrm{a}}$ instância administrativa) constantes na sede da entidade e nas Coordenações de Vigilância Sanitária em Portos, Aeroportos, Fronteiras e Recintos Alfandegados nos Estados; - aguardando análise de recurso para revisão (retratação) constante na sede da entidade.

(ii) o quantitativo geral de processos administrativos sanitários decorrentes de infração à legislação sanitária aguardando elaboração de parecer recursal para fins de análise pelo Colegiado da Anvisa ( $2^{a}$ instância administrativa).
\end{abstract}

Resposta da Anvisa relativa ao questionamento enviada, por e-mail, aos autores em 5 de julho de 2016 às $17 \mathrm{~h} 46 \mathrm{~min}$ :

Em atenção a sua solicitação, informamos que o pedido foi indeferido, com base no art. 13, II do Decreto $\mathrm{n}^{\circ} 7.724 / 12$, por ter sido considerado, no momento, pedido de caráter desproporcional. Ressaltamos que o caráter desproporcional de um pedido de acesso à informação não decorre propriamente do pedido em si, mas da capacidade responsiva do órgão ou entidade. Representa-se quando, para atendimento à demanda, a Administração é levada a enfrentar dilemas de alocação de recursos em um ambiente em que tais recursos são escassos. No caso em tela, o levantamento solicitado levaria diversas áreas da Anvisa sede e todas as Coordenações dos Estados a realizar um denso trabalho de pesquisa (pois solicitou-se diversos dados de todos os processos decorrentes de infração à legislação sanitária). Ainda, em 05/02/16, foi publicado o novo regimento interno da Anvisa, que promoveu a reestruturação de diversas áreas e, desde então, os setores vem promovendo reestruturações físicas, reorganização de processos e adequação de métodos e procedimentos. Ou seja, o atendimento da pesquisa solicitada imporá à Administração uma dispersão desproporcional de recursos humanos escassos e a necessidade de sacrificar outras demandas relacionadas à atividade precípua das áreas.

Recursos dos autores registrado no e-Sic sob o no 25820002967201679 em 06/07/2016 às 10h08min pelo site http://esic.cgu.gov.br/sistema/site/index.html 2 ReturnUrl=\%2fsistema, bem como à Ouvidoria da Anvisa registrada sob o n ${ }^{\circ} 676352$ em 23/07/2016 pelo site http://portal.anvisa.gov.br/fale-com-a-ouvidoria 
e-Sic:

Recorro da negativa de informação da Anvisa referente ao protocolo de atendimento $\mathrm{n}^{\circ} 2016257968$ este, por sua vez, registrado no Anvisatende sob o n 675076, ambas transcritas abaixo. Cuida-se de pedido de informação sobre o quantitativo geral e atual de processos administrativo-sanitários da Anvisa, ainda em trâmite, ora indeferido sob o risível argumento de desproporcionalidade do pedido em razão da sua ineficiente "[...] capacidade responsiva do órgão ou entidade", pois requereu-se "[...] diversos dados de todos os processos decorrentes de infração à legislação sanitária." e que, portanto, levaria a instituição "[...] a realizar um denso trabalho de pesquisa [...]". Vejamos. Apenas solicitei (repito) números (in)exatos sobre "[...] o quantitativo geral (e atual) de processos administrativo-sanitários da Anvisa" que ocorrem em três momentos processuais distintos geridas, regimentalmente, por duas áreas técnicas internas, a Coordenação de Análise e Julgamento das Infrações Sanitárias - Cajis e Coordenação de Análise e Instrução de Recursos da Inspeção e Fiscalização - Corif, cristalizada nos art. 152 e 153 da RDC no 61, de 3/2/2016. Do exposto, repiso a solicitação por se tratar de pergunta simples de informação de dados mínimos que requer uma simples resposta que qualquer instituição pública tem (teria) seu controle.

\section{Ouvidoria da Anvisa:}

Solicitei informações relativas ao quantitativo de processos administrativos sanitários em trâmite na Anvisa, contudo as respostas que estão chegando não constam dados relativo a localidade/origem. Vejamos. A Anvisa me enviou em 21 de julho de 2016 as 11:34 com o assunto: ANVISA - resposta ao protocolo 2016290149 e, em 21 de julho de 2016 as 09:47, com o assunto: RESPOSTA AO PROTOCOLO ANVISA-2016290192, ambos para o meu e-mail (joedson.delgado@hotmail.com) com informações sobre a situação processual dos processos administrativos sanitários, contudo SEM QUALQUER REFERÊNCIA QUANTO A SUA ORIGEM E LOCALIDADE. A qualidade da informação, da forma que estão me enviando, é péssima. Devo deduzir tratar-se de respostas esparsas das CVPAF's enviadas a Ouvidoria já que a CAJIS me repassou os dados, faltando ainda, dados da CORIF e da GGPAF. Portanto, peço a gentileza, que a Anvisa me repasse tais informações solicitadas apondo, ao menos, qual a Coordenação (CVPAF) que está fornecendo a informação, caso contrário, tais dados são imprestáveis.

\section{Informações prestadas pela Anvisa pós-recursos, por e-mail, via e-Sicn n 25820002967201679 em 19/07/2016 às 16h46min e via Ouvidoria da Anvisa no 676352 em 26/07/2016 às 00h00min:}

\section{e-Sic:}

Com base nas informações fornecidas pela Coordenação de Análise e Julgamento das Infrações Sanitárias CAJIS, área técnica afeta ao assunto questionado, em atenção à sua solicitação (protocolo n 2016267632 , 
verificamos que a solicitação demanda três áreas diferentes da Anvisa, quais sejam: CAJIS (quantitativo de processos administrativos sanitários que aguardam decisão inicial e juízo de retratação, na sede da Anvisa), GGPAF (quantitativo de processos administrativos sanitários que aguardam decisão inicial e juízo de retratação, nas CVSPAFs dos Estados) e CORIF (quantitativo de processos administrativos sanitários que aguardam parecer recursal para análise pelo Colegiado da Anvisa). Como cada área deve responder os dados de sua competência, e para que o protocolo não fique em tramitação entre essas áreas (alongando a resposta à demanda), a CAJIS informará, neste protocolo, os dados referentes ao processos de sua competência. Para resposta aos outros dados, foram criados no SAT outros dois protocolos ( $n^{\circ} 2016283902$ e n ${ }^{\circ}$ 2016283923), direcionados respectivamente à CORIF e à GGPAF. Ressaltamos que, desde 05/02/16, com a publicação do novo regimento interno da Anvisa, a CAJIS não faz mais parte da GGPAF, razão pela qual os dados dos processos nos Estados serão respondidos pela GGPAF.

Dessa forma, informamos que, na CAJIS/DIMON (Anvisa sede), existem cerca de 600 processos administrativos sanitários aguardando decisão inicial (1ª instância administrativa), e cerca de 1.780 processos administrativos sanitários aguardando análise de recurso para juízo de retratação. Os demais dados solicitados serão respondidos pela CORIF e pela GGPAF, por meio dos protocolos $\mathrm{n}^{\circ}$ 2016283902 e n 2016283923 , respectivamente.

\section{Ouvidoria da Anvisa:}

Após analisarmos o pedido inicial formulado por V.Sa, constante do protocolo SAT no 2016267632 e, sua reclamação na presente demanda, respondemos o que segue. Primeiro, cumpre salientar que é da CAJIS - Coordenação de Análise e Julgamento das Infrações Sanitárias, a competência para o julgamento em primeira instância dos processos administrativos sanitários (PAS), originados das unidades subordinadas à Diretoria de Monitoramento. Portanto, a informação que repassamos não abrange a totalidade de PAS em trâmite na Anvisa. Especificamente, com relação ao seu questionamento, cumpre à CAJIS responder os seguintes itens:

i) o quantitativo geral de processos decorrentes de infração à legislação sanitária que se encontram: - aguardando decisão inicial ( $1^{\text {a }}$ instância administrativa) constantes na sede da entidade e nas Coordenações de Vigilância Sanitária em Portos, Aeroportos, Fronteiras e Recintos Alfandegados nos Estados; - aguardando análise de recurso para revisão (retratação) constante na sede da entidade. Diante do solicitado, conforme último levantamento realizado em Junho/2016, informamos que a quantidade aproximada de processos aguardando julgamento em $1^{\text {a }}$ instância, no âmbito da CAJIS (sede) e, nos Estados, com autoridades delegadas, é de 2.094 processos. E, para análise de recurso e juízo de retratação temos aproximadamente, 2.645 processos. Quantidade, também, referente ao que consta na CAJIS e autoridades delegadas nos Estados. Por fim, informamos que os processos não são separados por localidade/origem. Trabalho que demandaria um trabalho de pesquisa além da possibilidade da área. 


\section{APÊNDICE B}

Pedido de informações dos autores registrada na Ouvidoria da Anvisa sob o n $^{\circ} 662761$ pelo site http://portal.anvisa.gov.br/fale-com-a-ouvidoria

Solicito informações do quantitativo de processos administrativo-sanitários (período de competência de 2011 a 2014) originários de infração sanitária da Lei nº 6.437/1977 que foram declarados prescritos (por prescrição trienal e a quinquenal) pela área técnica da GGPAF e GGIMP (atual GFIMP), inclusive os que foram objetos de apuração funcional pela Corregedoria.

\section{Informações prestadas pela Ouvidoria da Anvisa nº 2016038519, por e-mail, em 20/01/2016 às $15 \mathrm{~h} 58 \mathrm{~min}$ acerca do quantitativo de processos sancionadores prescritos:}

Em resposta à sua solicitação, informamos que o pedido foi indeferido, com base no art. 13, II do Decreto $\mathrm{n}^{\circ} 7.724 / 12$, por ter sido considerado, no momento, pedido de caráter desproporcional. Ressaltamos que o caráter desproporcional de um pedido de acesso à informação não decorre propriamente do pedido em si, mas da capacidade responsiva do órgão ou entidade. Representa-se quando, para atendimento à demanda, a Administração é levada a enfrentar dilemas de alocação de recursos em um ambiente em que tais recursos são escassos. No caso em tela, não há no sistema dados para realizar o levantamento solicitado, o que levaria a área a realizar um denso trabalho de pesquisa em cada processo. Ou seja, o seu atendimento imporá à Administração uma dispersão desproporcional de recursos humanos escassos e a necessidade de sacrificar outras demandas relacionadas à atividade precípua da área.

\section{Recursos dos autores ao Sistema Eletrônico do Serviço de Informações ao Cidadão regis- trado no e-Sic no 25820000277201685 em 20/01/2016 às 17h30min:}

Recorro da negativa de informação da Anvisa referente ao protocolo de atendimento n 2016038519 este, por sua vez, reiterado pelo protocolo de atendimento n ${ }^{\circ} 662761$. Cuida-se de pedido de informação sobre o quantitativo de processos administrativo-sanitários da Anvisa (período de competência de 2011 a 2014) originários de infração sanitária da Lei n 6.437/1977 que foram declarados prescritos (por prescrição trienal e a quinquenal) pela área técnica da GGPAF e GGIMP (atual GFIMP). Estes, inclusive, foram objetos de apuração funcional pela Corregedoria, contudo teve a informação sonegada/negada sob o lacônico jargão da norma "desproporcionalidade". A propósito, esta informação consta: 1) nas áreas técnicas da Anvisa que analisam e julgam a conduta infracional, a exemplo regimental da GGPAF e GFIMP (ex-GGIMP); 2) na Corregedoria que foram enviadas centenas de feitos prescritos para apuração da responsabilidade funcional do(s) servidor(es) que lhe deram causa. 
No mais. Esta informação deveria constar do Relatório de Gestão do Exercício de 2014 que foi divulgado pela Anvisa ao TCU e a sociedade em 2015.

\section{Informações prestadas pela Anvisa pós-recurso acima, via e-Sic no 25820002967201679 , 25820000277201685 em 15/02/2016 às $11 \mathrm{~h} 42 \mathrm{~min}$ :}

Com base nas informações fornecidas pelo Gabinete do Diretor-Presidente - Gadip, área técnica afeta ao assunto questionado, informamos que em atenção ao seu questionamento a Coordenação Técnica de Análise e Julgamento de Infrações Sanitárias em Portos, Aeroportos, Fronteiras e Recintos Alfandegados - Cajis e a Gerência-Geral de Fiscalização de Produtos Sujeitos à Vigilância Sanitária GGFIS esclarecem que não possuem a informação requerida de forma sistematizada e que o trabalho de pesquisa e compilação manual dos dados, para o atendimento de uma demanda individual, imporia às áreas um esforço excessivo que resultaria em prejuízo de suas atividades rotineiras, causando prejuízo à coletividade. Diante do exposto, com base no inciso II, art. 13 do Decreto 7.724/2012, justificam a impossibilidade de atendimento ao pedido de acesso à informação. Esclarecem ainda que a prescrição de um processo administrativo sanitário pode ser reconhecida, inclusive, pela Decisão da Diretoria Colegiada em segunda instância. Já a Corregedoria informa que: "o quantitativo de Processos Administrativos Sanitários prescritos que chegaram a esta Corregedoria somam 1.633 (mil seiscentos e trinta e três) processos. 


\title{
APÊNDICE C
}

\author{
Pedido de informações dos autores registrada na Ouvidoria da Anvisa sob o n ${ }^{\circ} 2016124824$ \\ em 22/03/2016 às 15h08min através do site http://www.anvisa.gov.br/institucional/faleco- \\ nosco/FaleConosco.asp
}

Indago a Auditoria Interna da Anvisa se já houve algum trabalho de auditoria nas unidades organizacionais julgadoras de infrações à legislação sanitária federal no âmbito dos serviços de saúde; de produtos derivados do tabaco; de produtos sujeitos à vigilância sanitária, propaganda, publicidade e promoção; de portos, aeroportos, fronteiras e recintos alfandegados, notadamente sobre as multas (sanção pecuniária) no período de 2011 a 2015.

\section{Informações prestadas pela Ouvidoria da Anvisa n ${ }^{\circ} 2016124824$, por e-mail, em 24/03/2016 às $18 \mathrm{~h} 10 \mathrm{~min}$ :}

Em atenção a sua solicitação, informamos que não houve trabalhos de auditoria no escopo e período solicitado. Adicionalmente, informamos que consta ação de auditoria no Plano Anual de Atividades de Auditoria Interna - exercício 2016 em tema que permeia o escopo solicitado (multas). $\bigcirc$ trabalho já foi iniciado, possui previsão de finalização para a primeira quinzena de maio e possui os seguintes objetivos: GERAL Avaliação dos procedimentos de lavratura, instrução, análise e decisão dos processos administrativos sanitários relativos a autos de infração sanitária (AIS) e/ou multas que tenham sidos cancelados por nulidade, insubsistência e/ou erro formal, compreendidos entre o período de janeiro a dezembro de 2015. ESPECÍfICOS Avaliação dos controles internos implementados pelas unidades auditadas e utilizados no processo de trabalho; Avaliação dos procedimentos de lavratura dos autos de infração sanitária que deflagraram a abertura do processo administrativo sanitário; Avaliação dos processos administrativos sanitários quanto ao cumprimento das formalidades processuais, considerando os elementos e requisitos de instrução processual, prazos, emissão dos atos administrativos e as decisões proferidas; Identificar e quantificar os processos administrativos sanitários relativos a autos de infração sanitária (AIS) e/ou multas que tenham sido cancelados por nulidade, insubsistência e/ou erro formal e apontar as possíveis causas que desencadearam os respectivos cancelamentos; Avaliação dos procedimentos de cobrança administrativa das multas; Demonstrar os resultados financeiros decorrentes da perda de receitas, em face de multas não recolhidas, e os possíveis impactos na arrecadação e na gestão do processo de trabalho. 


\section{APÊNDICE D}

Pedido de informações dos autores registrado no e-SIC sob o n $00075000340201632 \mathrm{em}$ 23/03/2016 às $15 \mathrm{~h} 58 \mathrm{~min}$ pelo site http://esic.cgu.gov.br/sistema/site/index.htmleReturnUr$1=\% 2$ fsistema

Indago a Controladoria-Geral da União (CGU) se já houve algum trabalho de auditoria nas unidades organizacionais julgadoras da Anvisa relativas as infrações à legislação sanitária federal (Lei $n^{\circ}$. 6.437/19777) no âmbito dos serviços de saúde; de produtos derivados do tabaco; de produtos sujeitos à vigilância sanitária, propaganda, publicidade e promoção; de portos, aeroportos, fronteiras e recintos alfandegados. Referi-me, então, às multas (sanção pecuniária) aplicadas pela Anvisa, no período de 2011 a 2015, nos mesmos moldes da auditagem da CGU realizada no Relatório de Auditoria Anual de Contas do exercício de 2013 nas atividades da Câmara de Regulação do Mercado de Medicamentos (CMED) - Processo n 25351.127980/2014-53, Relatório no 201406165, UCI Executora: SFC/DSSAU - Coordenação-Geral de Auditoria da Área de Saúde.

Informações prestadas pelo CGU, via e-SIC, protocolo $\mathrm{n}^{\circ}$ 00075.000340/2016-32 em 31/03/2016 às 13h59min:

1. Em atendimento a sua solicitação, informamos que a Controladoria-Geral da União - CGU não realizou auditorias que tratassem sobre a atuação da Agência Nacional de Vigilância Sanitária - Anvisa no julgamento de infrações sanitárias. 2. Adicionalmente, destacamos que estão disponíveis no site da CGU os relatórios de ações de controle em que a Agência Nacional de Vigilância Sanitária - Anvisa foi a unidade auditada. Poderá acessar os citados relatórios no endereço eletrônico http:// sistemas.cgu.gov.br/relats/relatorios.php?linha_atuacao $=$ TODOS\&ano $=\&$ titulo $=$ anvisa\&ministerio $=$ Sa $\%$ C3\%BAde\&ano_exercicio $=\&$ programa $=$ Selecione $\& u f=$ Selecione $\&$ municipio $=$ Selecione. Atenciosamente, SECRETARIA FEDERAL DE CONTROLE INTERNO Controladoria-Geral da União. 


\section{APÊNDICE E}

Pedido de informações dos autores registrado na Central de Atendimento ao Público - Anvisa pelo site atendimento.central@anvisa.gov.br sob o no 681301 em 03/10/2016 às 00h00min:

Gostaria que me informasse se a Diretoria Colegiada da Anvisa já aprovou alguma Súmula, nos termos do inciso VIII, artigo 53, da RDC n 61, de 03 de fevereiro de 2016? Em caso positivo, quais são estas súmulas da Dicol?

Informações prestadas pela Anvisa, por e-mail, protocolo no 2016421310 em 6/10/2016 às $12 \mathrm{~h} 22 \mathrm{mim}$ :

Em atenção a sua solicitação, informamos que a Anvisa não possui nenhuma Súmula aprovada.

Data da submissão: 15 de março de 2018 Aceito em: 09 de abril de 2018 